http://dx.doi.org/10.18778/8142-006-8.04

\title{
DEFying GENRE STEREOTYPES IN FrANCES HodGSON BURNETT's THE SECRET GARDEN AND A LITTLE PRINCESS
}

\author{
KAROLINA MARZEC \\ Institute of English Studies, University of Lodz
}

Children's literature is a vast genre which employs many tropes and motifs worth discussing, however, it has been, surprisingly, ignored by scholars for many years. The genre, until recently, has been undervalued as light reading, and although it is educational for the young recipient, it has not been considered as providing deep analytical meaning and insight. Books of this genre were to help children adapt to rudimentary social norms, standards of behaviour and propriety. Since adults were considered educated when it came to these terms, this style of writing was recognised as irrelevant for them. Nevertheless, things have changed and, as Paula S. Fass states, "the history of children and childhood is a new and energetic field of inquiry that provides critical insights into the human past and contemporary social experience" (xi). Being one of the scholars who research children's literature, Fass underlines the significance of the genre as a valuable testimony of how societies change and develop, but, most importantly, she explains how literature for the youngest readers has finally gained its respect:

This explosion of historical scholarship into previously underexplored or unexplored arenas was one of the signal achievements of social science in the second half of the twentieth century. Social history broke down the tight walls of earlier historical scholarship that was largely confined to an exploration of the people at the top and the politics of power. In breaching those walls, scholars allowed children to come into view. (xi)

The moment children started to be perceived as significant members of the society, the role of literature solely devoted to them and about them also rose. The messages one finds in children's literature speak not only about the child's position, but they also characterise the writer who conveys them. One has to remember that it was by all means adults who were responsible for some of the most prominent fiction dedicated to children. And among them, there is also Frances Hodgson Burnett. The moment, however, when an adult 
starts analysing a work for a younger generation, they find depth and allusions that were not obvious for the original target readers.

While children are often the perceived audience for these texts, adult perceptions of the difficulties at the heart of the project mean that they provide a richer, multilayered reading experience for adults as well as children. Of course, it must be remembered that the childhoods portrayed in fictions, whether based on an ideal or an author's own, are always a fiction; a construction dependent on the Romantic image of the innocent linked to the feminine. The awareness of the adult writer and adult reader of the desire to portray this lost world in fiction deepens the sense of loss. It is the growing self-consciousness of this fictionality that marks the difference in tone in children's literature as we move toward the Modernist period. (Thacker 54)

As Thacker puts it, there is a hidden message of a lost world that the author communicates throughout their work, and which can be understood only by another adult reading it. These are the messages that are yet to be discovered when the child reader grows older, bearing in mind the fondness for the book they once read, or messages that should be there in plain sight for the adult reader, who also might learn something new from reading a children's novel. Yet, some adults might display a considerable reluctance to a children's book. One must, thus, understand that the writers who have achieved success in children's literature usually touched upon political and social issues. What is the most interesting, however, is the fact that Burnett's writing consists of a strident critique of the status quo in the British society and of proposals of changes which can, and, should be implemented by her readers. These are definitely notions which are way beyond the understanding of the youngest recipients; nevertheless, a close reading by a more mature audience allows them to realise the importance of the discussed novels.

Although for many readers Burnett is only recognisable as the author of timeless children's novels, she was an established and popular writer, with a substantial number of published titles:

Burnett published more than fifty novels, most of them for adults, and wrote and produced thirteen plays. She was the highest-paid and best-known woman author of her time, and from the time she was eighteen and published a short story in Godey's Lady's Book and Magazine her work was never turned down by any publisher. (Gerzina ix)

Her own life and experience can exemplify the breaking of the stereotype of an obedient housewife who lives only to serve within the patriarchal system and who follows the rules she does not agree with, and submissively waits all her life for a man to provide for her. Being the self-made woman Burnett 
truly was, she tried to put some of her own experience into her books, and inspire younger generations to change the world they live in or at least change the way they perceive it. Many critics, nevertheless, do not see the notions conveyed in her books as the ones reaching beyond the standard and obvious motifs. For some scholars, for example for Roderic McGillis, A Little Princess is a standard "school story" (Gender and Empire 17); for others, The Secret Garden is merely a story about dealing with a loss of a beloved person. One of the critics claims that "The Secret Garden is about the completion of a process of mourning. It is the completion of this process, for Mary, for Colin, and for Colin's father, moreover, which makes possible the image of the family restored with which the book concludes" (Gohlke 899). All these observations may be true within different analytical aspects, however, they show a very typical way of approaching Burnett's work. Nevertheless, since different scholars point out different features of the novels as the most prominent ones, this paper is meant to prove that, above all, Frances Hodgson Burnett was displeased with the British society and the values it represented, most importantly, with the space of the genre stereotypes that ruled within the industry of children's literature and among ordinary people in her times. The analysis is to prove that by writing her novels, Burnett sends timeless messages to her readers and inspires generations, as the values she cherishes are still on demand even in our times.

The beginning of the twentieth century was marked by many social changes; it was the time of women fighting for their independent position within the society. As Jenni Murray says, "the twentieth century will, without doubt, be viewed by historians as the Woman's Hour;" Burnett must have been influenced by the changes of which she was a witness. The author watched women grow more powerful in their willingness to change their situation, and although they were not very successful at the beginning, they began the struggle and infused many other people with their ideas and spirit. Murray notes that the suffragists "were unsuccessful in their immediate objective;" nevertheless, "in the early part of the century the suffragists argued powerfully, but peacefully for the vote." From the position of a writer, Burnett could also inspire the younger generations, and although she does not openly support the women's movement, she opposes to the stereotypes ruling children's literature. Jan Susina points out that:

Victorian children's literature reflected the culture's separate spheres for men and women with different types of books written for girls and boys. Stories for girls were often domestic and celebrated the family life, such as Alcott's Little Women or Kate Douglas Wiggin's Rebecca of Sunnybrook Farm (1903). Stories for boys, such as MARK TWAIN's The Adventures of Tom Sawyer 
(1876) and its sequel Adventures of Huckleberry Finn (1884), encouraged boys to have adventures. (182)

Gender thus had an immense influence on children's literature, as writers had a tendency to create different stories depending on the target reader. If the story was to be read by boys, it had elements of adventure and danger, encouraging the readers to idealise the protagonists and favourably follow their examples. The same point of view was applied to stories for girls, however, young women were to follow the domestic lifestyle, learn how to behave in society, respect customs and traditions, and play the part of "the angel in the house." Nevertheless, Susina argues that it was not only the fictional protagonist who played a major role in the distinction within literature:

Children's literature historically has been more open to women as authors and illustrators because it has been considered less significant than adult literature and because publishers have regarded women as more capable of teaching and raising children. Children's literature also began to segment itself in terms of social class as penny dreadfuls, or dime novels, were produced for the working class and more high-minded literature was produced for the middle and upper classes. (183)

One may say that Burnett, being a woman, had surprisingly an easier start as a children's literature writer. Nevertheless, she did not write stories in the already presented manner, which made her a pioneer of a kind, a person who defies the already accepted norms. Her books present a slightly different aspect of what was usually credited as literature for girls and young women. That is why she had to show great determination in getting her messages across and reaching such a broad readership.

A Little Princess shows a plethora of examples how Frances Hodgson Burnett points out the mistakes and cruelties of the British society in her times. By following the story of the protagonist, one is shown that children were looked down upon, treated like objects, not able to speak for themselves. Miss Minchin - the owner of the school Sara goes to - looks at the child only through the perspective of her personal benefit, not allowing the girl to speak when necessary and constantly expressing her frustrations over Sara's sudden impoverishment. A French lesson where Sara is not asked whether she can speak the foreign language is one of the most prominent examples showing Miss Minchin's attitude:

'As your papa has engaged a French maid for you,' she [Miss Minchin] began,

'I conclude that he wishes you to make a special study of the French language.' 
Sara felt a little awkward.

'I think he engaged her,' she said, 'because he - he thought I would like her, Miss Minchin.'

'I am afraid,' said Miss Minchin, with a slightly sour smile, 'that you have been a very spoiled little girl and always imagine that things are done because you like them. My impression is that your papa wished you to learn French.' (A Little Princess 23)

This attitude is presented throughout the scene: Sara is forced to talk to the French teacher without being able to explain that her mother was French, and that she has been speaking French since as far as she can remember. It is the French teacher, astonished and amazed by the girl's fluency and accent, who finally allows her to speak and, thus, allows her unintentionally to prove Miss Minchin wrong:

'Ah, madame,' he said, 'there is not much I can teach her. She has not learned French; she is French. Her accent is exquisite.'

'You ought to have told me,' exclaimed Miss Minchin, much mortified, turning on Sara.

'I - I tried,' said Sara. 'I - I suppose I did not begin right.'

Miss Minchin knew she had tried, and that it had not been her fault that she was not allowed to explain. (A Little Princess 26)

This passage can serve only as a small example of how the girl is treated throughout the book: always scorned, never allowed to speak for herself.

In the case of Sara, however, it was also the financial status that played a major part in the way she was treated by adults as well as her peers; for the benefit of the plot a personal vendetta of Miss Minchin was used to somehow justify the cruelty. The child is not given a voice of her own and she is often enough spoken for instead of listened to. Within the issue of child labour and child abuse, the character of Becky plays a dominant part as she is most inhumanely exploited, whereas Anne, a beggar girl who is helped by Sara, serves as a self-reliant respectable girl who, when treated like a human being, changes her position from a victim of poverty to a child with perspectives, and who is arguably the girl with the best chance to be treated as an equal subject in the whole story. These are definitely uncommon issues for a children's novel to be presented.

In The Secret Garden Burnett continues to criticise the British society, but she shows a different approach, focusing on the imperialistic issues which influence children's well-being. The colonial child she presents both in Mary Lennox and in Colin Craven is juxtaposed with the image of the Romantic child - a healthy and strong young person. Although one has to be aware that Burnett cannot be perceived as a postcolonial writer, she shows traces of a 
changing mindset. The neglected and disagreeable Mary is, thus, presented as emotionally detached because of her parents' focus on the Empire and entertainments:

Her father had held a position under the English Government and had always been busy and ill himself, and her mother had been a great beauty who cared only to go to parties and amuse herself with gay people. She had not wanted a little girl at all, and when Mary was born she handed her over to the care of an Ayah, who was made to understand that if she wished to please the Memsahib she must keep the child out of sight as much as possible. So when she was a sickly, fretful, ugly little baby she was kept out of the way, and when she became a sickly, fretful, toddling thing she was kept out of the way also. (The Secret Garden 1)

This is the passage that opens the book, proving from the very beginning that the author does not express any sympathy or fondness towards Mary's parents. Later in the novel, an objective observer comments on Mary's father and mother, as well as on their attitudes towards the child, once it is noticed that the child is spoiled and contrary:

'Perhaps if her mother had carried her pretty face and her pretty manners oftener into the nursery, Mary might have learned some pretty ways, too. It is very sad, now the poor beautiful thing is gone, to remember that many people never even knew that she had a child at all.' (The Secret Garden 9)

By presenting the parents as the most detestable guardians, Burnett takes an anti-imperialist position, proving that Mary's overuse of power over servants derives from her parents' egoistic approach. Again, a brave idea to present such matters at the beginning of the twentieth century.

Even though these books - from the historical point of view - cannot be classified as postcolonial ones, the tropes of postcolonialism become more prominent once the reader realises that the stories are about a child who is not allowed to speak for themselves or about the imperialistic power abuse that is manifested in the way a protagonist treats a servant. The above mentioned examples in A Little Princess (1905) and in The Secret Garden (1911) can be perceived as a critical comment on the British society. Nevertheless, from the contemporary point of view, they show the marks of a postcolonial thinking and Roderick McGillis states that "obviously, Burnett's evocation of India in both The Secret Garden and A Little Princess has a colonialist aspect that has remained unnoticed until recently" (Voices of the Other xxvii) and that the novel written in 1911 "is a decidedly 'colonial' book, but one we need to examine from a postcolonial perspective" ("Postcolonialism, Children, and their Literature" 11). 
In the sense of defying the genre stereotypes in both books, the idea of imperialism, colonial writing, postcolonial criticism and gender should also be discussed, as some of these notions played a crucial role in the literature which inspired Burnett to take such a critical stand in her own writing. Deborah Thacker states that

The colonising force of fiction to inculcate hegemonic ideologies or to reinforce gender roles is powerful through the history of children's literature, yet there are also texts which seek to resist or challenge this controlling process. The element of the fantastic, and the various attempts to speak directly to children in the most enduring texts of the late nineteenth century, offer an appeal to the 'feminine' and an entrenched loyalty to the Romantic image of children of the early part of the century. (54)

It is already known that Burnett criticised the British society, nevertheless, it was not yet mentioned specifically in terms of gender roles and female stereotypes. One of the books that was popular and had a profound impact on the young readers and writers was Robinson Crusoe, a novel by Daniel Defoe strongly pervaded with colonial values. McGillis comments that

It set the standard for the boy's adventure story, and it presented a strong argument for Britain's imperialist enterprise. Many are the books that appeared in the nineteenth century telling the story of one or more young men, and sometimes women, marooned on some tropical isle or lost in some barren land where they claim possession of the land through their ability to cultivate it and fashion a garden in the wilderness. (Gender and Empire 11)

When McGillis talks about cultivating a garden, he raises an uncomfortable issue again. Burnett created in the discussed books two female protagonists who oppose the genre standard and who take up the roles of adventurers of their own kind. Although the novelist could not represent the ideas of the postcolonial analysis of literary texts, she lived in a world that was already undergoing pivotal changes in the mindset. McGillis points out that "part of the postcolonial enterprise is a liberation from the diminishing placement of people according to their racial origins, their religious beliefs, their gender, or their sexual preference" ("Postcolonialism, Children, and their Literature" 13) and this is what the author does - she puts her protagonists in situations which were not common for young girls, breaking the habit of putting them in inferior positions, applying tropes of the adventurous books written for the male audience. McGillis points out that

Burnett cannot completely escape the imperial ethos of her time. In fact, little Sara is something of a Crusoe at home in that she manages to construct for herself civilized living space in a modern urban wasteland represented by 
Miss Minchin and her single-minded business practices and by the poverty visible in the London streets. She manages to do this not with the rational, ordered, businesslike acumen of Crusoe himself but with imaginative flare and feminine sympathies. (Gender and Empire 13)

The scholar juxtaposes $A$ Little Princess and Defoe's book, claiming later that Robinson Crusoe represents the rational and $A$ Little Princess the romantic aspect, nevertheless, the similarities of the protagonists dealing with hostile and unfavourable environment still remain. Sara deliberately represents the female virtues, as a new protagonist, not a copy of a male hero, but one who demonstrates that women are capable of coping with disadvantages and still retain emotions they are stereotypically associated with. When it comes to The Secret Garden, McGillis writes that

Burnett ... did participate in the debate over women's roles, and her position is present in her fiction. . . . As in The Secret Garden (1911), Burnett's position is ostensibly conservative. She champions the female as nurturer, a dispenser of largesse and a person willing to sacrifice for others, especially for men. The complexity here has to do with Burnett's incorporation and feminine revision of what I think of as the "Crusoe syndrome". The "Crusoe syndrome" is simply the imperial enterprise that was all pervasive late Victorian England. Indeed, as Edward Said has noted, one did not have to be a conservative to sympathise with England's imperial designs: "With few exceptions, the women's as well as the working-class movement was pro-empire." Burnett's female version of the Crusoe story accepts the imperial myths while it also promotes the woman's cause. (Gender and Empire 11)

The passage shows the complexity of the story, nevertheless, one may argue that if Burnett truly champions the idea of women sacrificing for the benefit of men, then, it does not follow why Mary should be a strong figure who focuses throughout the book mostly on her own well-being, although the way she does that crucially changes at the end of the novel. She is not a character willing to put herself at stake for the benefit of a male protagonist. The incorporation of the imperial myth of conquest and cultivation of land, however, is visible once the reader starts perceiving Mary also as the coloniser who wishes to control not only her life, but also the garden - she finds an abandoned, uninhabited piece of land and through her work she makes it thrive. Donald Hall points out that Mary "is participating in the same project that her colonial parents did; by exposing the hidden and taming a wild place, she is rendering secure a potentially threatening world" (53). It was as far as Burnett could go in reversing the stereotypes considering gender in children's novels, however, her message is clear when she puts Mary in charge of the story, making her the protagonist who is active and opposes the 
implied role models one would like to impose on a young girl. Susan McLeod writes that The Secret Garden "is a mystery novel of sorts, where a clever girl encounters two puzzles and in solving them discovers that they are related" (424); and to put is simply, Mary as an active and adventurous protagonist embodies what books for boys and with male protagonists usually presented. McGillis states that

Indeed, at the end of the century one of the main challenges for the woman writer, especially one who supported women's rights, was to present successfully the female's role in the expanding British Empire. Because literary convention had emphasized the gentle and passive nature of the female - the so-called angel in the house ideal put forth by Coventry Patmore - the thought of the young woman taking part in dangerous exploration in the barbarous lands was nor readily countenanced. (Gender and Empire 12)

Nonetheless, the moment when the books are published qualifies as the beginning of the next century, and that is why Burnett has more courage to stand up to the stereotypes concerning not only the plot but also the way the protagonists are created. The usual "angel in the house" image is dismissed in order to design protagonists who are honest, rebellious and who present traces of independence. Sara Crewe is definitely in defiance when she does not want to express her feelings in front of Miss Minchin. She also presents persistence, patience and assiduity when it comes to her new position in life. McGillis comments that "A Little Princess has much to say about a female's strength of character, her imaginative ability, her ability to learn, her education and her place within the social order" (Gender and Empire 11). Nevertheless, and above all, Sara is rebellious. One may argue that she persists in her stubbornness because she is a well-raised child; still, it is not only Miss Minchin that Sara feels so passionate about. When Becky is accused of stealing, she vigorously defends her. When Lottie, another girl studying at Miss Minchin's school, is bullied by other girls, Sara is the one to defy them and to look after the younger student. McGillis says that "she has passion, and passion that can burst out uncontrollably" (Gender and Empire 24) and he cannot be more right. He additionally points out that "the narrator admits that Sara 'was not an angel' ...., reminding us just how her character differs from the standard Victorian 'angel in the house"' (Gender and Empire 24). Throughout the book Sara shows the autonomy of her character, regardless of her financial status. She is never helpless and makes her own decisions.

Although Mary in The Secret Garden has less possibility to show her independence, she is a strong character who also does not fit the Victorian stereotype. As Marion Gymnich and Imke Lichterfeld state, Mary Lennox "is 
no demure little angel in the house" (11). As an active protagonist, she presents herself as an explorer and adventurer, who seeks and finds the garden. She has to solve the mysteries of the manor, as well as undergo her inner metamorphosis, nevertheless, she does not conform to the stereotype of the silent and obedient young woman. She does what she pleases, speaks her mind without hesitation and artificial shyness. There are, nonetheless, many scholars, such as Lisa Paul, Elizabeth Keyser or U.C. Kneopflmacher, who claim that Mary fades from the view, as Colin dominates the last third of the book, nevertheless, they are dismissed by Gunther who comments that they are missing the point of the whole book (159). The scholar takes issue with such statements and says that

children do not see Mary as displaced by Colin, and, until it is suggested to them, nor do most adult readers. My sense is that these readers believe she is not displaced but in fact remains the key figure throughout. In quest terms, she advances so much further along the path of self-discovery than does Colin that we cannot help but experience her as more important. Add to this the fact that what Colin does achieve is predominantly a product of Mary's wisdom and effort rather than his own, and we begin to have a true picture of the impact of this book. (Gunther 160)

Mary stays the dominant figure of the book, as she claims the garden and passes her knowledge to Colin. Gunther additionally goes as far as to say that it is Mary who "remains the initiator in their relationship" (161), granting the girl an active position which some critics deny her. Burnett creates a protagonist who is dynamic and undergoes an inner transformation. In the discussed novels, the author does not conform to the stereotypes ruling the genre, and she presents the reader with two young girls who are willing to develop, show the strengths of their characters and inspire younger generations to be brave, independent, energetic and determined.

Frances Hodgson Burnett, influenced by the changes within the society, presents characters who oppose the stereotypes and influence target readers, yet these are not only the narrative figures of her novels who defy the norms in the children's literature. In her stories, Burnett demonstrates a severe critique of the British society, commenting on the position of a child in general, as well as the colonial influences on their upbringing. Focusing on the characters of Sara and Mary, the author converts the typical colonial image suggested by novels such as Robinson Crusoe to her own needs. The writer presents the girls in the seemingly domestic environment, however, she also allows them to embark on their own adventures, which, at the same time, opposes the stereotypical space of literature for young girls. She, thus, dismisses the popular image of the "angel in the house" and forges rebellious 
Defying Genre Stereotypes in Frances Hodgson Burnett's The Secret Garden... 51

and active characters who were usually associated with male target readers. Sara is passionate and willing to provide help for other people, and Mary, although underestimated and undervalued by some critics, is still bold, independent and she undergoes a marvellous transformation throughout the book, offering a new role model to follow. Gymnich and Lichterfeld accurately conclude that Mary's "hot temper, her strong will and her bonding with male characters on largely equal terms turn her into a predecessor of female heroines of later twentieth-century children's literature" (11). This could not be a better summary of what Burnett did in the discussed novels - she shaped the grounds for the future writers to form female protagonists who inspire readers, and most importantly, who challenge the status quo.

\section{Works Cited}

Burnett, Frances Hodgson. A Little Princess. Penguin Books, 1996.

---. The Secret Garden. Harper Press, 2010.

Fass, Paula S. Preface. Encyclopedia of Children and Childhood: In History and Society, edited by Paula S. Fass. Macmillan Reference USA, 2004.

Gerzina, Gretchen Holbrook. Preface. The Secret Garden, by Frances Hodgson Burnett, edited by Gretchen Holbrok Gerzina. Norton, 2006, pp. ix-x.

Gohlke, Madelon S. "Re-reading The Secret Garden." College English, vol. 41, no. 8, April 1980, pp. 894-902.

Gunther, Adrian. "The Secret Garden Revisited." Children's Literature in Education, vol. 25, no. 3, 1994, pp. 159-168.

Gymnich, Marion and Imke Lichterfeld. "The Secret Garden Revisited." A Hundred Years of The Secret Garden: Frances Hodgson Burnett's Children's Classic Revisited, edited by Uwe Baumann, Marion Gymnich and Barbara Schmidt-Haberkamp. Bonn University Press, 2012.

Hall, Donald E. "'We and the World': Juliana Horatia Ewing and Victorian Colonialism for Children." Children's Literature Association Quarterly, vol. 16, 1991, pp. 51-55.

McGillis, Roderic. A Little Princess: Gender and Empire. Twayne Publishers, 1996.

---, and Meena Khorana. "Postcolonialism, Children, and their Literature." ARIEL: A Review of International English Literature, vol. 28, no. 1, January 1997.

---. Voices of the Other: Children's Literature and the Postcolonial Context. Routledge, 2000. 
McLeod, Susan H. "A comment on Madelon S. Gohlke's 'Re-Reading The Secret Garden'." College English, vol.43, no. 4, April 1981, pp. 423-425. Murray, Jenni. " $20^{\text {th }}$ Century Britain: The Woman's Hour." BBC History, 3 March 2011. http://www.bbc.co.uk/history/british/modern/jmurr_01.html. Accessed 26 August 2016.

Susina, Jan. "Children's Literature." Encyclopedia of Children and Childhood: In History and Society, edited by Paula S. Fass. Macmillan Reference USA, 2004.

Thacker, Deborah Cogan. "Victorianism, Empire and the Paternal Voice." Introducing Children's Literature by Deborah Cogan Thacker and Jean Webb. Routledge, 2002. 